\title{
Artroszkópiával kiegészített mini arthrotomiában végzett humán lateralis meniscus transzplantáció
}

\author{
Esetbemutatás \\ DR. VÁNCSODI JÓZSEF, DR. BODA ORSOLYA, DR. FAZEKAS ÁDÁM, \\ DR. BÁRDOS TAMÁS, DR. VERMES CSABA \\ DOI: $10.21755 / \mathrm{MTO} .2015 .058 .0203 .008$
}

Érkezett: 2015. február 25.

\section{ÖSSZEFOGLALÁS}

A meniscus funkciók szerepe a térdízületben kiemelkedően fontos: tompítják a lépésekből származó ütéseket, rugalmasságuknál fogva segítik a térd mozgását, szerepük van a terhelő felszíneket borító hyalinporc táplálásában, a stabilitás növelésében és fenntartásában. A elmúlt néhány évtizedben számos technikát kidolgoztak, amely a részleges vagy teljes meniscus deficit pótlását célozta. A szerzők saját betegük esetének ismertetésével demonstrálják a meniscus transzplantáció területén szerzett tapasztalataikat, mely operációt artroszkópiával asszisztált mini arthrotomiában végeztek el. A meniscust csontos blokkal implantálták, olyan 44 éves páciensnek, akinek meniscus hiányból fakadó korai osteoarthroticus panaszai voltak a jobb oldali térdízület lateralis compartmentjében. A sikeres meniscus transzplantációt követően azt tapasztalták, hogy a meniscus allograft transzplantáció valóban képes csökkenteni a fájdalmat és javítani a térd ízületi funkcióját, ezzel hozzájárul a páciens fájdalommentes, normál fizikai aktivitásához. Jelenleg betegük túl van a posztoperatív 48 hónapos időtartamon, ízületi funkciói jók, korábbi panaszai megszúntek. A beavatkozás előkészítése során áttekintették a meniscus operációkkal kapcsolatos szemléletváltást a nemzetközi irodalomból származó adatok alapján, amelyeket közleményükben röviden összegeztek.

\section{Kulcsszavak: $\quad$ Arthrosis; Arthrotomia; Artroszkópia; Meniscus; Transzplantáció;} Térdízület;

J. Váncsodi, O. Boda, Á. Fazekas, T. Bárdos, Cs. Vermes: Transplantation of human lateral meniscus through arthroscopy-assisted mini arthrotomy. Case report

Meniscus functions play an extremely important role in the knee joint: they attenuate the shocks caused by footsteps, promote knee movements due to their elasticity and contribute to the nutrition of hyaline cartilage covering the weight bearing surfaces; they also increase and maintain the stability of the joint. Numerous techniques were developed for the replacement of partial or total meniscus defects in the last few decades. The authors share their experience in meniscus transplantation demonstrating the case of their patient treated with arthroscopy-assisted mini arthrotomy. The meniscus was transplanted as one unit with a bone block in case of a 44 years old patient, who had symptoms of early osteoarthritis in the lateral compartment of his right knee caused by the absence of the lateral meniscus. They observed that successful meniscus allograft transplantation actually decreased pain and improved knee joint functions, contributing to the patient's normal, pain free physical activity. Surgery was performed 48 months ago; his knee joint functions are good and previous complaints ceased. Prior to surgery, authors reviewed the changes in principles of meniscus surgery available in the literature, which are summarized in their publication.

Keywords:

Arthritis - Surgery; Arthroscopy - Methods; Knee joint - Surgery; Menisci, tibial - Tansplantation; Transplantation, homologous; 


\section{BEVEZETÉS}

A meniscus a térdízület félhold alakú, energiaelnyelő páros szerve, a combcsont condylusai és a tibia plató között. A megfelelő meniscus funkció alapvetően fontos a térdízület normális múködéséhez. A meniscusdeficittel élő térdízület magán viseli az arthrosis skarlátbetújét, amely az arthrosis kockázatának szignifikáns emelkedését és az egészséges ízületi funkció elvesztését jelenti; a totál meniscectomián átesett páciensek esetében tizenötszörösre emelkedik a korai térdízületi arthrosis kockázata (13). Álló testhelyzetben a meniscusok 40-60\%-kal csökkentik a teherviselő, illetve a terhelés-átviteli erőket, így a normális és ép meniscus funkció jelentős puffer hatással bír a terhelő erőkkel szemben, amely védelmet jelent a hyalinporc számára. Emellett az ízület stabilitásában és kongruenciájában is fontos szerepe van. Mindezek ismeretében érthető, hogy a meniscus(ok) hiánya jelentősen fokozza az osteoarthrosis kockázatát az adott compartment(ek)ben. Ennek megfelelően az utóbbi két évtizedben a totál meniscectomia mútéti megoldása felől, a meniscus megtartó, illetve meniscus pótló mútétek irányába terelődött a célzott mútéti terápia. Az elkerülhetetlenül bekövetkezett totál meniscectomiát követően lehetőség nyílik allografttal történő meniscus pótlásra, amely jelentősen csökkentheti a beteg panaszait, illetve a későbbi osteoarthrosis kockázatát $(2,5,13,20)$. A közelmúltban számos mútéti technikával próbálkoztak pótolni a hiányzó meniscust és funkcióit, beleértve az autológ szöveti transzplantációt, úgymint patella-ín, Achilles-ín, semitendinosus ín autograftokat (4, 11, 12), zsírpárna autograftot (10) és autológ borda perichondrium graftokat (1), titán graftokat (7), szénszálas szöveteket (24), Dacront (21) és Teflont (17). Ezek a különféle újítások azonban többnyire rossz hatásfokkal múködtek. A szemléletváltás Milachowskinak köszönhető, aki először közölt adatokat humán donorból származó meniscusszal történő allograft transzplantációról (18). Napjainkig több ezer meniscus transzplantáció történt világszerte, jó posztoperatív hatásfokkal. Fontos a megfelelő mútéti indikáció felállítása, amely főbb pontjai a következők:
- Fiatal páciens (15-55 év), akinek a kórtörténetében meniscectomia szerepel, az érintett compartmentre lokalizálódó korai arthrosisos tünetek, úgymint fájdalom, diszkomfort érzés

- Olyan páciens, akinél a transzplantált meniscustól várható a jobb ízületi stabilitás

- Megfelelő csontkorú páciens (15-55 év), akinél felszínpótló eljárás a következő években kontraindikált, fiatal életkorra való tekintettel

- Konzervatív terápiára nem reagáló, izolált meniscus hiányból fakadó krónikus fájdalom

- Képalkotó eljárással, vagy korábbi mütéti lelettel egyértelmúen igazolt meniscus hiány

- Pontosan dokumentált degeneratív folyamat (maximum Grade II-es chondropathia, $<50 \%$ ízületi rés beszűkülés)

- A transzplantációtól várható jó térdízületi biomechanika, illetve ízületi stabilitás (16)

Komplex mútéti megoldás számos kérdést felvet, úgymint a megfelelő mútéti technika kiválasztását, a donor-recipiens pontos méretegyezésének megítélését, a graft tárolásának megfelelő módját, illetve a posztoperatív rehabilitáció formájának megfelelő kiválasztását.

Célunk e beszámolóval bemutatni a lateralis meniscus allograft transzplantáció területén szerzett korai tapasztalatainkat, mely operációt arthroscopiával asszisztált mini arthrotomiaban végeztük $(3,14,25)$.

\section{ESETISMERTETÉS}

\section{Betegkiválasztás}

Betegünk egy 44 éves nőbeteg volt, BMI 28, akinél 28 évvel korábban - trauma következtében - elkerülhetetlen volt a mindkét compartmentre kiterjedő, totál meniscectomia elvégzése a jobb térdízületben, amely beavatkozást más intézetben végezték. A beteg korai, arthroticus tünetegyüttessel 
kereste fel klinikánk ambulanciáját, ahol a konzervatív kezelés mellett radiológiai kivizsgálást indítottunk. A nőbeteg fizikai státuszában a következők szerepeltek: beszűkült ízületi funkciók, flexió 10-100 fok, véghelyzetben fájdalommal, minimális hydrops, megtartott szalagfunkciók, mindkét compartmentben nyomásérzékenység. Tengelylefutásban enyhe valgus eltérés mutatkozott, teljes alsóvégtagi

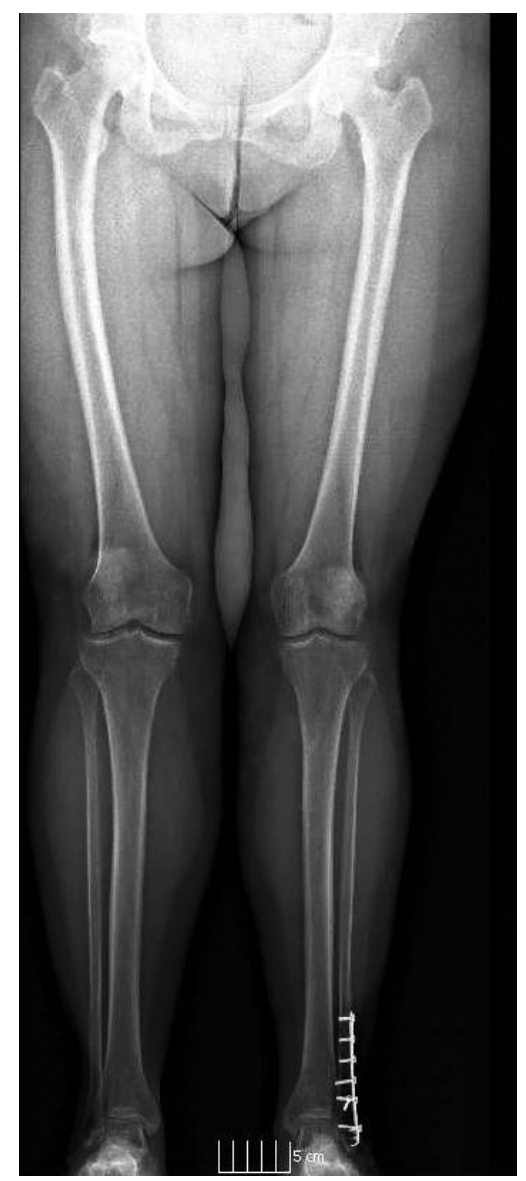

1. ábra Preoperativ teljes alsóvégtagi röntgenfelvétel, amely megfelelö tengelyállást mutat röntgenfelvételen (1. ábra). A radiológiai lelet az ízfelszínek közötti diszkrét beszűkülésről, illetve az ízfelszínek közötti enyhe fokú subluxatióról számolt be (2. ábra). Komplex kivizsgálást követően, a beteget alkalmasnak találtuk meniscus allograft transzplantációra a nemzetközi ajánlásokat figyelembe véve, amelyeket a bevezetésben részletesen ismertettünk (16).

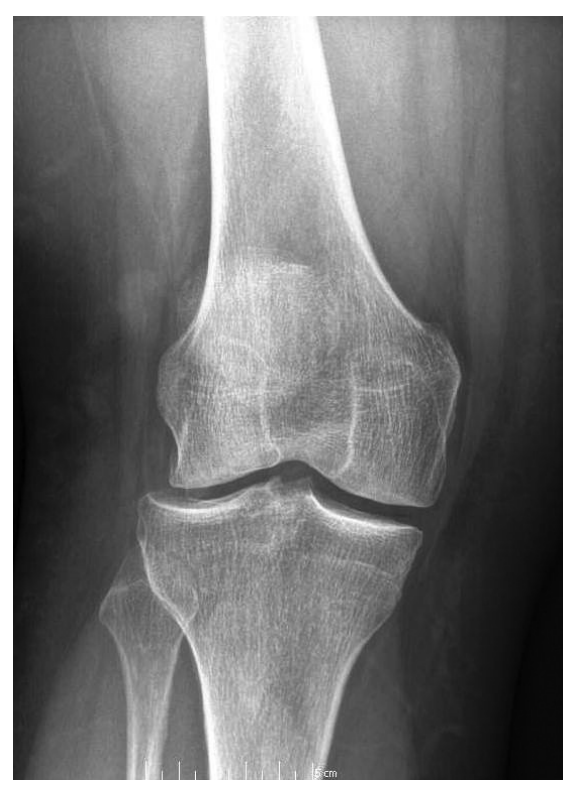

2. ábra Preoperativ álló röntgenfelvétel, enyhe arthroticus jelekkel, kis fokban subluxált ízületi felszínekkel 


\section{MÓDSZER}

Donor kritériumok: a donor minden szempontból megfelelt az érvényben lévő, magyarországi szabályozás által előírt, vesetranszplantációra alkalmas donorkritériumoknak. Intakt musculosceletaris rendszerū, jó állapotban lévő donorból asepticus körülmények között távolítottuk el a graftot, amely jelen esetben csonthíddal rendelkező lateralis meniscus volt (3. ábra). A megfelelő recipiens kiválasztása során figyelembe vettük a donor és a recipiens nemének, a testmagasságának és testtömegének egyezését, ezen túl röntgenfelvételek alapján kontrolláltuk a donor és recipiens ízületi méreteinek egyezését. A testmagasság, illetve ízületi méretegyezés maximum 10\% eltérést engedélyez a donor és a recipiens között $(14,16)$. Fontos a donor részéről az intakt musculosceletalis rendszer, és a donor meniscus kivétele során az ép meniscus test, illetve az ép meniscus szarvak $(14,16)$. A donorszövet kivétel során az identikus térdízületből, a meniscust kipreparáltuk és a lateralis tibia platóval együtt távolítottuk el. A nemzetközi ajánlások $72 \mathrm{~h},+4$ ${ }^{\circ} \mathrm{C}$ történő szövet tárolást javasolnak, számos lehetséges konzerváló folyadékot ajánlva. Esetünkben steril körülmények között, 48 óra időtartamig, $+4{ }^{\circ} \mathrm{C}$ hőmérsékleten DMEM-ben (Dulbecco modified Eagle's medium) tároltuk a meniscusgraftot $(15,16)$.

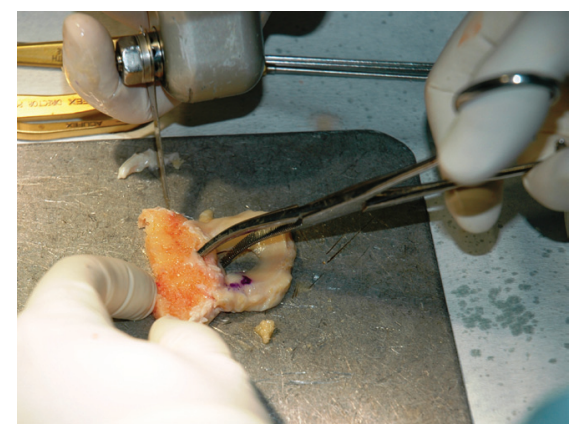

3. ábra Preoperativ méretezés, a megfelelő csonthíd eszközös kialakítása
A meniscust csontos blokkal, az úgynevezett "csonthíd" technikát alkalmazva ültettük be páciensünkbe. A beavatkozás során vértelenségben artroszkópiát alkalmaztunk, amelyet a mútét második felében szükségszerűen kiegészítettünk lateralis mini arthrotomiával. A méretre vágás a szövetbankolást követően, a beültetést megelőzően történt (3-4. ábrák). A páciens lateralis compartmentjében eszközös csontcsatorna kialakítása törcént, a csonthíd méretének megfelelően. A graft bevezetését és helyzetét artroszkópos kamerával ellenőriztük. A meniscus graftot a csontos csatornában intraossealis, felszívódó varratokkal stabilizáltuk, a meniscust pedig az ízületi tok lefutásának megfelelően rögzítettük a tokhoz. Ez utóbbi metódus a meniscus túlélése szempontjából különösen fontos, ugyanis revascularisatiót követően a tok felől kap tápláló arteriolákat. A beültetést követően artroszkópiával ellenőriztük a graft stabilitását passzív ízületi mozgások során.

A graft utánkövetését standard térd röntgenfelvétellel (5. ábra) és MRI vizsgálattal (6. ábra) végeztük. A röntgenvizsgálatot a posztoperatív első napon, majd azt követően a kontrollvizsgálatok alkalmával több ízben végeztünk, MRI vizsgálat a posztoperatív 6. és 18. hónapokban történt.

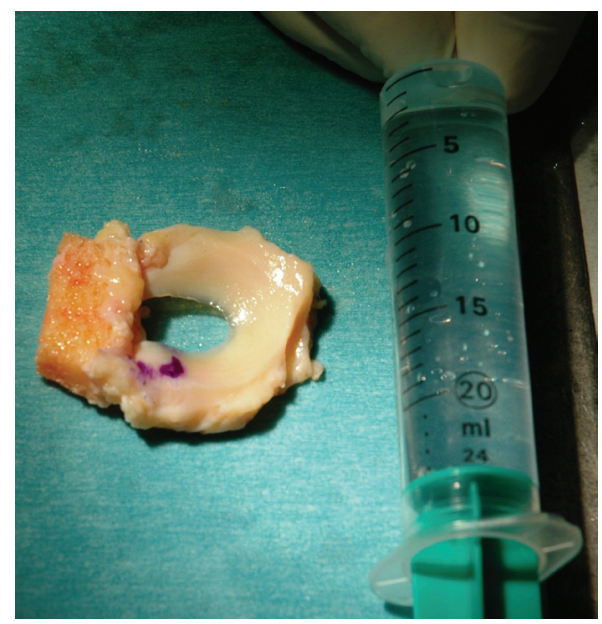

4. ábra A méretre vágott, beültetésre előkészitett meniscus, jól látható az intakt meniscus test, az eszközösen kialakitott csonthíd 

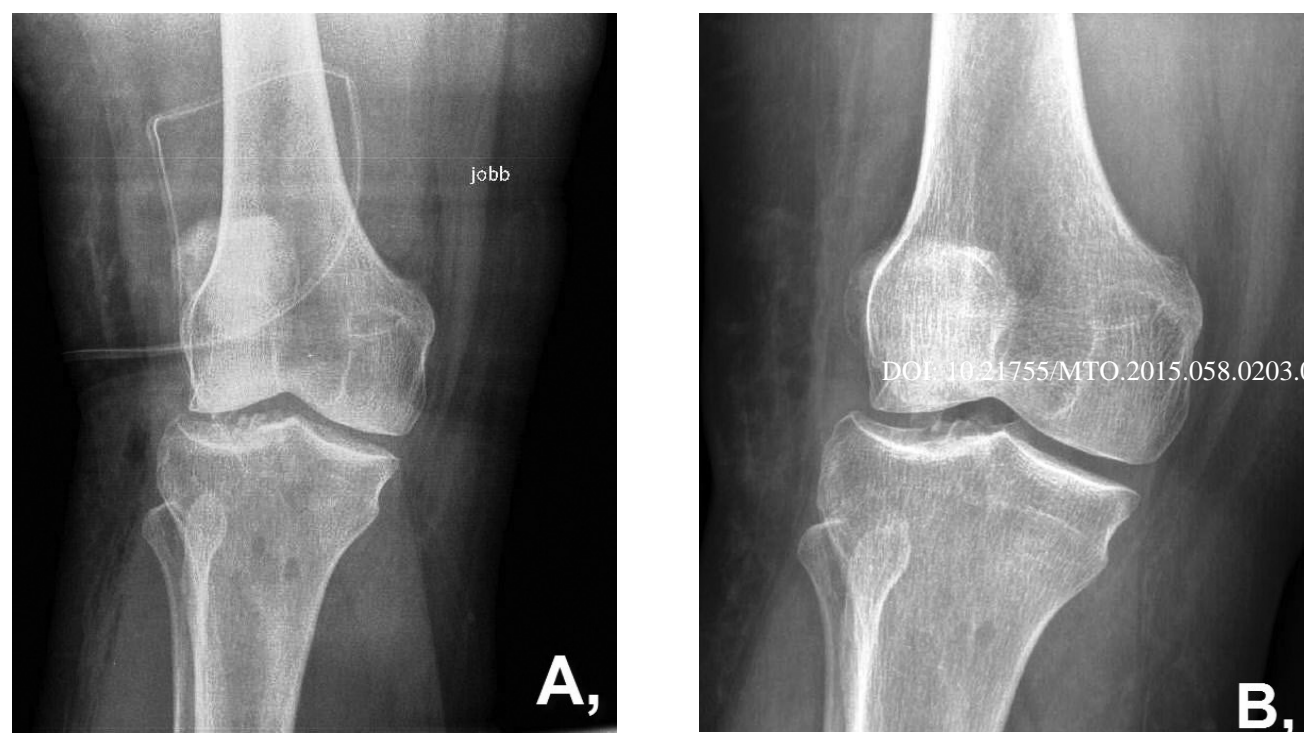

\section{5. ábra}

(A) Posztoperativ AP röntgenfelvétel, a drain ábrázolódik, illetve a tibia csonton látható az intraosszeális rögzítő furatok vetülése

(B) Posztoperativ 18. hónapos, terhelt AP röntgenfelvétel, amelyen szimmetrikus ízületi rés ábrázolódik, a beültetett csonthíd területe az átépülés jeleit mutatja

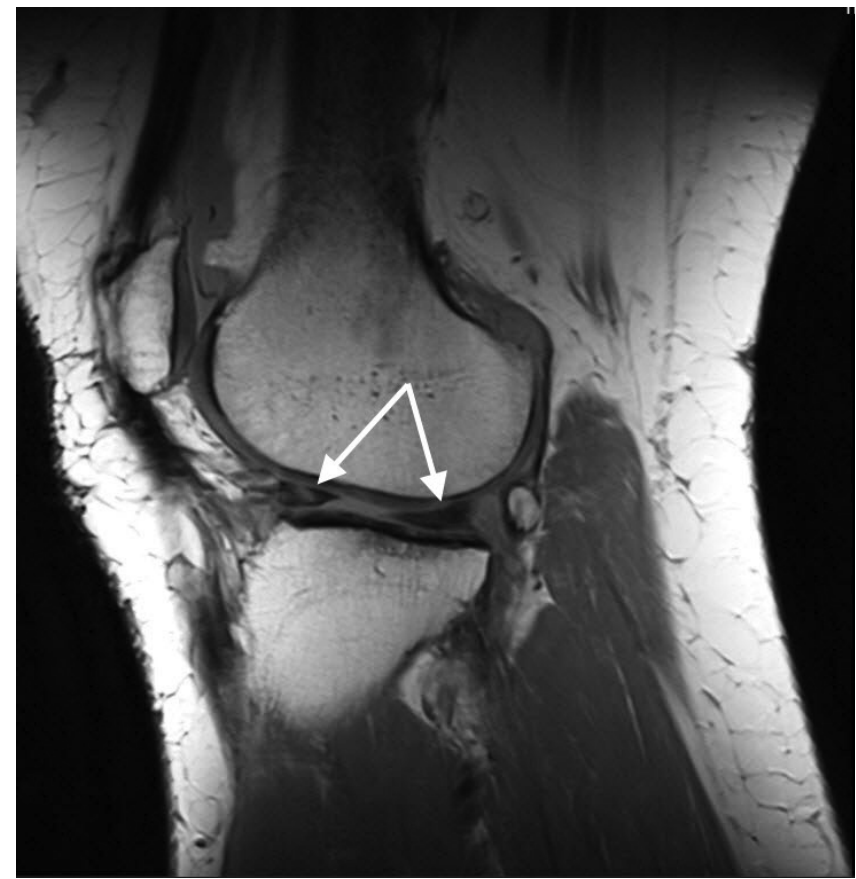

6. ábra Posztoperativ 18. hónapos $3 T$ MR felvétel, amelyen a beültetett, túlélt meniscus (fehér nyilak) jól ábrázolódik 


\section{EREDMÉNYEK}

Munkánk során a megfelelő méretegyezésű meniscus graftot alkalmasnak találtuk transzplantációra olyan páciens esetén, akiknél korábban meniscus eltávolítást végeztek. A posztoperatív rehabilitáció során a következők szerint jártunk el: Az első 3 hétben teljes extenzióban történő brace rögzítés végeztünk, majd azt követően hetente $10^{\circ}$-kal növeltük a flexiót, így a 12 . hét végére értük el a $90^{\circ}$-os flexiót. Az első 3 hétben teljes tehermentesítést, majd a következő 6 hétben részterhelést rendeltünk el, a teljes terhelést a 10 . héttől engedélyeztük. Kezdetben passzív, majd aktív gyógytornát indítottunk, amelye gyógytornász felügyelt, a hatodik posztoperatív hónap végéig, amikor a flexió értéke $105^{\circ}$ volt. A képalkotó eszközökkel (röntgen, MRI) készített felvételek a transzplantált meniscus graft integrációját mutatták a recipiens térdben 6 , illetve 18 hónappal a mútétet követően, normál tengelyállás, jó csontos integráció mellett. A fizikális vizsgálatok 18 hónappal a beavatkozást követően a következő értékeket mutatták: flexió $0-115^{\circ}$, nem volt nyomásérzékenység és hydrops, szalagok tartottak, nem észleltünk crepitatiót. A páciensünk kielégítő mértékű fájdalom csökkenésről és életminőség javulásról számolt be.

\section{KÖVETKEZTETÉS}

A két évtizedes nemzetközi múlttal rendelkező meniscus allograft tranaszplantáció (MAT) az irodalomban közöltek alapján olyan mútéti módszer, amelynek hosszú távú utánkövetése jó eredményekről számolt be. Az utánkövetések rendre rávilágítanak arra a tényre, hogy fizikális vizsgálómódszerekkel, illetve nemzetközileg validált pontrendszerekkel (Lysholm score, VAC, IKDC, SF-36) a térd állapota, a mútét sikeressége megítélhető, de a beültetett meniscus valós állapotának megítéléséhez a second look artroszkópia a legalkalmasabb utánkövetési módszer, azonban ennek invazivitása, perioperatív szövődmények lehetősége miatt nem követendő metodika (19). Általános a konszenzus azt illetően, hogy a megfelelően magas mágneses indukcióval (3T) elvégzett MR képalkotás alkalmas lehet jó közelítéssel a meniscus valódi strukturális állapotának és vitalitásának megítélésére $(8,19)$. Azon esetekben, ahol valamilyen egyéb oknál fogva ismételt artroszkópiát végeztek, a transzplantált meniscus állapotát 80\%-ban gyógyultnak ítélték (8). A MAT-ot követően 36 hónappal a fájdalom jelentős csökkenéséről és/vagy teljes megszűnéséról, az ízületi funkciók szignifikáns javulásáról, 40 hónappal pedig, femoralis és tibialis területen MR képalkotással diagnosztizált egyértelműen jobb hyalinporc kondícióról találunk közlést (9). A közép- és hosszú távú utánkövetések tükrében, az ízületi funkciók jelentős javulását, az ízületi szabad folyadék aịimiriálóciását és összességében a totál meniscectomián átesett térdízület állapotának szignifikáns javulását vártuk $(6,13,22)$.

Klinikánkon a megfelelő előkészítést és a szükséges feltételek biztosítást követően, transzplantációra alkalmas cadaver meniscust távolítottunk el, amelyet a nemzetközi ajánlásban elvártak szerint konzerváltunk aszeptikus körülmények között (16). Megfelelő, alapos preoperatív tervezés és donor-cadaver méretegyezést követően (méretbeli eltérés kisebb volt, mint $10 \%)$ artroszkópiás mútétet kiegészítő mini arthrotomiából sikeresen végrehajtottuk a jobb térdízület lateralis meniscus transzplantációját. Megfelelő radiológiai módszerekkel (röntgendiagnosztika, MRI), fizikális vizsgálatokkal, jó meniscus funkciót diagnosztizáltunk, amely tükrében az elvégzett operációt sikeresnek értékeltük. Rövid és középhosszú utánkövetés alapján tapasztalataink egybevágnak a nemzetközi irodalomban leírtakkal. E tapasztalataink birtokában kijelenthetjük, hogy a MAT valóban képes csökkenteni a térdízületi fájdalmat, az ízületi szabad folyadék mennyiségét és javítani az ízület funkcióját. Tekintettel a páciens fiatal életkorára, az operatív, minimál invazív módszerrel visszaadott, kielégítő meniscus funkcióra, az effektív és speciális eszközök nélkül kivitelezhető rehabilitációra, a cikk szerzői úgy vélik, a jövőben a hasonló kondíciókkal bíró meniscus hiány pótlása elvégezhető. Ugyanis a jövőben esetlegesen felmerülő, a kórelőzmény miatt szükségessé váló, operativ ízületi felszínpótlás időpontja jelentősen kitolódhat, illetve annak hosszú távú, életminőségre vetített hatásfoka jelenősen megnövekedhet (23). A hazánkban kiépült transzplantációs módszertan és a rendelkezésre álló eszközpark birtokában a beavatkozás költséghatékonyan elvégezhető, miközben a technika minimál invazivitása kapcsán nem éget fel hidakat egy későbbi, ízületi felszínpótló rekonstrukció előtt. 


\section{IRODALOM}

1. Bruns J., Kahrs J., Kampen J., Behrens P., Plitz W.: Autologous perichondral tissue for meniscal replacement. J. Bone Joint Surg. Br. 1998. 5: 918-923.

2. Chang H. C., Teh K. L., Leong K. L., Mak S. L., Karim S. A.: Clinical evaluation of arthroscopic-assisted allograft meniscal transplantation. Ann. Acad. Med. Singapore 2008. 37: 266-272.

3. Chen X. Z., Zhang J., Lin P., Zhang H., Hong L., Wang X. S., Song G. Y., Feng H.: Early graft failure after meniscus allograft transplantation: an unusual cause of using all-inside meniscal repair device. Chin. Med. J. 2013. 20: 3985-3987.

4. Johnson L. L., Feagin J. A. Jr.: Autogenous tendon graft substitution for absent knee joint meniscus: a pilot study. Arthroscopy. 2000. 2: 191-196.

5. Jungmann P. M., Li X., Nardo L., Subburaj K., Lin W., Ma B. C., Majumdar S., Link T. M.: Do cartilage repair procedures prevent degenerative meniscus changes? Am. J. Sports Med. 2012. 12: 2700-2708.

6. Kelly B. T., Potter H. G., Deng X. H., Pearle A. D., Turner A. S., Warren R. F., Rodeo S. A.: Meniscal allograft transplantation in the sheep knee: evaluation of chondroprotective effects. Am. J. Sports Med. 2006. 34: 1464-1477.

7. Kenny C.: Arthroscopic repair of avulsion of the posterior root and body of the lateral meniscus: a twenty-year follow-up. A case report. J. Bone Joint Surg. Am. 2009. 12: 2932-2936.

8. Kim C. W., Kim J. M., Lee S. H., Kim J. H., Huang J., Kim K. A., Bin S. I.: Results of isolated lateral meniscus allograft transplantation: focus on objective evaluations with magnetic resonance imaging. Am. J. Sports. Med. 2011. 39: 19601967.

9. Kim J. M., Lee B. S., Kim K. H., Kim K. A., Bin S. I.: Results of meniscus allograft transplantation using bone fixation: 110 cases with objective evaluation. Am. J. Sports Med. 2012. 40: 1027-1034.

10. Kohn D., Rudert M., Wirth C. J., Plitz W., Reiss G., Maschek H.: Medial meniscus replacement by a fat pad autograft. An experimental study in sheep. Int. Orthop. 1997. 21: 232-238.

11. Kohn D., Wirth C. J., Reiss G., Plitz W., Maschek H., Erhardt W., Wülker N.: Medial meniscus replacement by a tendon autograft. Experiments in sheep. J. Bone Joint Surg. Br. 1992. 6: 910-917.

12. Kohn D.: Autograft meniscus replacement: experimental and clinical results. Knee Surg. Sports Traumatol. Arthrosc. 1993. 1: 123-125.

13. Lee B. S., Kim J. M., Sohn D. W., II S.: Review of meniscal allograft transplantation focusing on long-term results and evaluation methods. Knee Surg. Relat. Res. 2013. 25: 1-6

14. Lee S. R., Kim J. G., Nam S. W.: The tips and pitfalls of meniscus allograft transplantation. Knee Surg. Relat. Res. 2012. 3: 137-145.

15. McDermott I. D.: What tissue bankers should know about the use of allograft meniscus in orthopaedics. Cell Tissue. Bank. 2010. 1: $75-85$.

16. Meniscal allograft transplantation - Medical policy. Chapter: Surgery: Procedures, Blue Cross and Blue Shield of Montana. (forrás: https://www.bcbsmt.com)

17. Messner K.: Meniscal substitution with a teflon-periosteal composite graft: a rabbit experiment. Biomaterials. 1994. 3: 223-230.

18. Milachowski K. A., Weismeier K., Wirth C. J.: Homologous meniscus transplantation. Experimental and clinical results. Int. Orthop. 1989. 1: 1-11.

19. Noyes F. R., Barber-Westin S. D., Rankin M.: Meniscal transplantation in symptomatic patients less than fifty years old. J. Bone Joint Surg. Am. 2004. 86: 1392-1404.

20. Scotti C, Hirschmann M. T., Antinolfi P., Martin I., Peretti G. M.: Meniscus repair and regeneration: Review on current methods and research potential. Eur. Cell. Mater. 2013. 26: 150-170.

21. Sommerlath K., Gallino M., Gillquist J.: Biomechanical characteristics of different artificial substitutes for rabbit medial meniscus and effect of prosthesis size on knee cartilage. Clin. Biomech. 1992. 2: 97-103.

22. Szomor Z. L., Martin T. E., Bonar F., Murrell G. A.: The protective effects of meniscal transplantation on cartilage: an experimental study in sheep. J Bone Joint Surg. Am. 2000. 82: 80-88.

23. Than P., Szuper K., Somoskeöy Sz.: Hibás pozícióban beültetett totál térdprotézis aszeptikus lazulása és reviziója. Esetismertetés. Magyar Traumatológia Ortopédia Kézsebészet Plasztikai Sebészet. 2012. 55: 79-84.

24. Veth R. P., Heeten G. J., Jansen H. W., Nielsen H. K.: Repair of the meniscus. An experimental investigation in rabbits. Clin. Orthop. Relat. Res. 1983. 175: 258-262.

25. Wajsfisza A., Meyera A., Makridisb K. G., Hardya P.: A new arthroscopic technique for lateral meniscal allograft transplantation: Cadaver feasibility study. Orthop. Traumatol. Surg. Res. 2013. 3: 299-304.

\section{Dr. Váncsodi József}

PTE Ortopédiai Klinika

7632 Pécs, Akác u. 1. 